\title{
Globalization in the Brazilian Amazon Region: Conflicting Answers from "Quilombo" Communities
}

\author{
Florent Kohler et al. ${ }^{*}$ \\ University of Tours, CREDA
}

France

\section{Introduction}

Globalization is a process that encompasses the accelerated and simultaneous circulation of ideas, goods, and human beings (Appadurai, 1996). In an Amazonian context, this chapter aims at analyzing the impacts of particular land status ownership on the resilience and flexibility of traditional communities facing globalization (Kramer et al, 2009).

The Amazon has been part of the global market since the 16 $16^{\text {th }}$ century: from the drogas do Sertão, through the rubber boom, to Brazil nuts (Bertholletia excelsa) and açaí (Euterpe oleracea), the global demand for Amazonian products has played a crucial role in the phases of human population of this rich basin (Bunker, 1985). Mark Harris (2006), following Moran and Parker, characterizes the "cabocla" populations by their ecological adaptations as well as their economic versatility.

During the 1990s and 2000s, a great number of "traditional" and/or indigenous communities were granted land rights in Brazil. Innovative legal statuses were created, either for the sake of environmental protection or as a function of the peculiar special social status of some social groups, mainly indigenous people and remnants of escaped slave communities (i.e. remnant quilombola communities). At the core of these rights is the recognition of a "special relationship" between these traditional communities and their territories. Due to the acknowledgement of this particular link, almost 30\% of the Legal Amazon is officially under the responsibility of traditional communities. ${ }^{1}$

However, traditional communities are now facing contradictory pressures induced by Brazilian public policies and globalization. On the one hand, they were granted land under

\footnotetext{
* Ludivine Eloy², François-Michel Le Tourneau ${ }^{3}$, Claire Couly ${ }^{4}$, Stéphanie Nasuti³, Dorothée Serges ${ }^{5}$, Sophie Caillon ${ }^{6}$, Guillaume Marchand ${ }^{1}$ and Anna Greissing ${ }^{3}$.

1 University of Tours, CREDA, France,

2 University of Montpellier III, UMR 5281 ART-Dev, France; University of Brasilia, CDS, Brazil,

3 CNRS, CREDA, France,

4 French Research Institute for the Development and the French National Natural History Museum, France,

5 CREDA, France,

6 CNRS, CEFE, France.

${ }^{1}$ Indigenous Lands cover $20 \%$ of the extension of the Legal Amazon, while Extractive Reserves (RESEX) and Sustainable Development Reserves (RDS) cover 4.84\%, and Quilombola lands cover 1.6\% (Ricardo and Rolla, 2009).
} 
the assumption that they would maintain their traditional way of life, with low impact on the ecosystems (Diegues, 1996). On the other hand, they are more and more connected to global markets and information technology, and have access to a greater mobility. They face the challenge of improving their living conditions by developing their economic activities. Globalization in this sense should not be understood as a single threat. Isolated forest communities have acquired the chance to access better rural living conditions. But traditional communities are confronted by a "double bind" situation: economic development and the extension of contemporary ecological ideology.

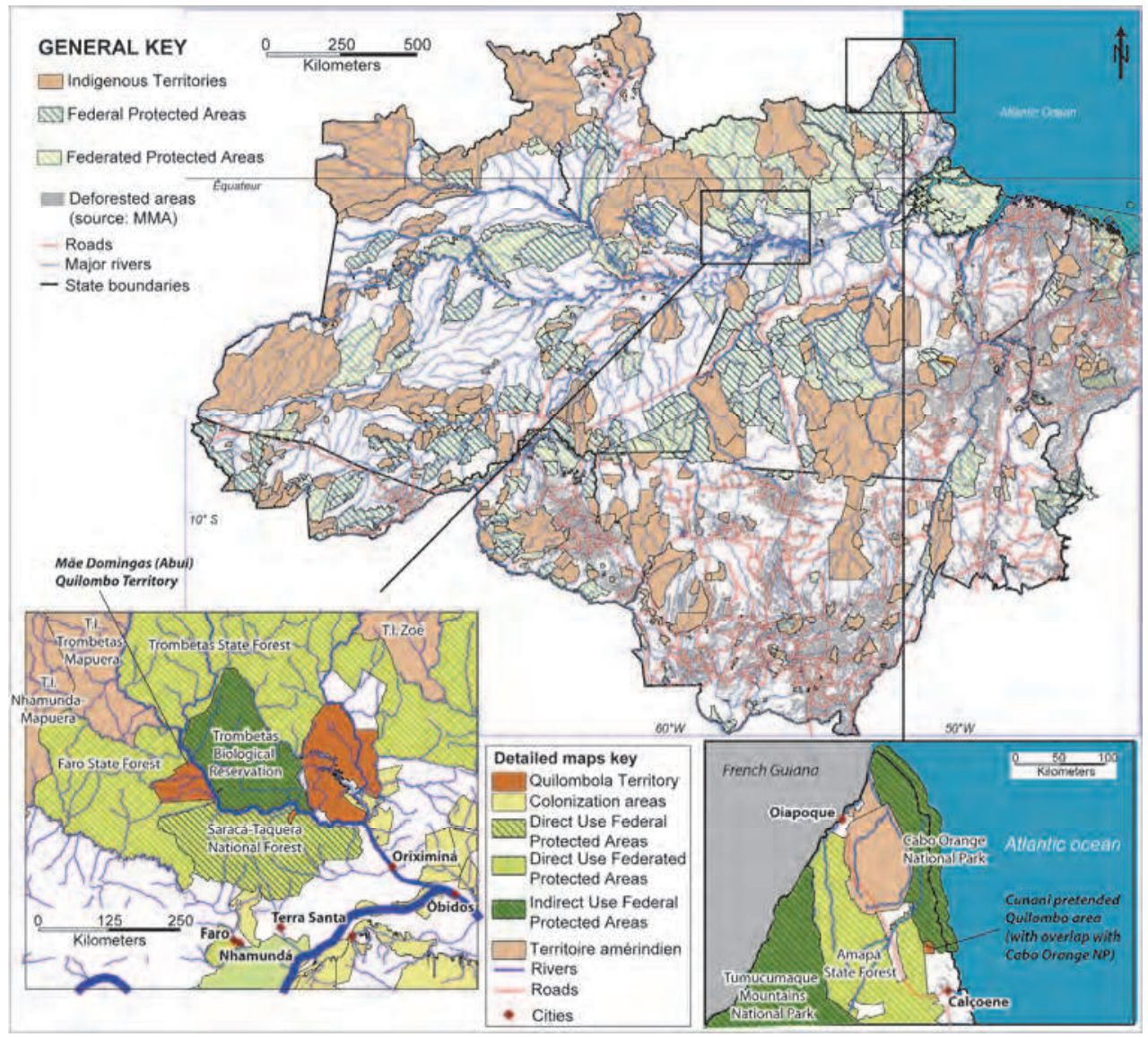

Fig. 1. Localization of the areas considered. Map by F.-M. Le Tourneau

Our work focuses mainly on the status of Quilombola, which we approach on the basis of two case studies in the Brazilian Amazon: one (the village of Cunani) in the Amapá state and the other one (the village of Abuí) in the Pará state. They experience contrasting demographic trends. The Cunani population, still waiting for its legal recognition, is decreasing. The village of Abuí, however, is included within a recognized quilombola land, its leaders are involved in the famous quilombola movement of the Rio Trombetas,and its 
population is increasing. While unveiling the current land-use situation, we investigate the benefits and consequences of two emerging commercial activities - ranching and açaí extraction. We study how the acquisition of land rights facilitates adaptation to the new economic context of the Amazon region.

\section{Globalization and the access to land rights: The ethnic strategy}

In "The Production of Locality" (1995: 213), Appadurai points to, among the effects of globalization, "the growing disjuncture between territory, subjectivity, and collective social movements". At the same time, the author underlines "the steady increase in the efforts of the modern nation-state to define all neighbourhoods under the sign of its forms of allegiance and affiliation".

In this context, indigenous or traditional populations occupy a special place. They are defined by the International Labour Organization (convention \#169, 1989) as having special ties with the territory they occupy, this territory being the guarantee and motor of their social (re)production.

Brazil was innovative in recognizing, in addition to ethnic categories (Amerindians and Quilombolas), another category, that of "traditional populations," defined not only by their activities and means of existence, but also by the transmission of their knowledge and practices from generation to generation (Barretto Filho, 2006). A number of the inhabitants of Amazonia can lay claim to one or another of these statuses, which differ in their degree of land rights: undivided joint ownership for the Quilombolas, usufruct for the Amerindians, and usage concessions for traditional populations. In order to be recognized as part of one or another of these groups, rural Amazonian communities need to adopt a universal dialectic of ethnicity and tradition.

The creation of quilombola territories is a response to a convergence between the global movement recognizing cultural diversity as being linked to biological diversity (UNESCO 2003), and the local movement of access to land. These two movements are mediated by the intervention of the Brazilian state, which imposes its structures and hierarchies in the creation of differentiated territories, for either nature conservation or cultural patrimonialization (Véran, 2002).

\subsection{The splendor and misery of Cunani}

The community of Cunani was formed over two periods. The first, that of the FrancoBrazilian Dispute (1770 - 1900), created an area frequented by French and Brazilian traders, while the main part of the population was composed of fugitive slaves. The latter, initially settling upriver, went on to colonize downstream as well. This period culminated with the proclamation of the short-lived "Republic of Cunani" (1882 - 1885), supported by the French, and ended in 1900 with the resolution of the Dispute in favor of Brazil. Then began a neo-Brazilian migration of people originally from the "islands" (south from Amapá and north-east from Pará). The two populations continued to intermingle, with the colonists returning upstream along the Cunani River.

Up until 1970, the inhabitants of Cunani benefited from a relative prosperity, though suffering the economic risks tied to the exploitation of Amazonian products: fur trade, fish, manatee oil, non-wood forest products, and logistical support for the garimpos of the region. Governor Janari, in the 1950s, began a politics of education that bore fruit. 
But the opening of BR156 linking Macapá to Oiapoque at the beginning of the 1970s changed all this: Calçoene, $50 \mathrm{~km}$ from Cunani, became the new economic centre of the region, leaving the enclaved communities to the side. A process of migration followed, due to the presence in town of commodities (health, education). The creation of the National Park of Cape Orange, in 1980, aggravated the situation, by restricting access to the Cunani River. With the increasing enforcement of environmental laws, the inhabitants of Cunani saw a continuously receding future. Finally, the route between Calçoene and Cunani, finished in 1987, is passable only part of the year, and at high transportation costs. The Amazonian "black gold" açaí, came too late for the possible creation of an Extractive Reserve (RESEX) bordering the Park. The projects of the Park management team concerning the community were quickly oriented toward equitable tourism, but the project never amounted to anything.

It was then that INCRA (National Institute for Colonization and Agrarian Reform, a branch of the Ministry of Agrarian Development charged with putting in place the process of surveying, demarcation, and land registry) intervened in the conflict between the community in outright decline and IBAMA (Brazilian Institute for the Environment and Renewable Resources). This intervention is part of a longstanding tradition of rivalry between the two federal organizations. In the struggle the community was waging for its survival and its remaining in place, the quilombola statute offered the advantage of a definitive land title. But the conversion of the inhabitants of Cunani into Quilombolas was not an easy thing: the local history was marked more by the Franco-Brazilian Dispute and by immigration from Pará than by the Quilombolas. As the oral traditions do not go back more than three generations, the identifying elements relative to belonging to Quilombolas are relatively recent contributions, contemporary with the community mobilization around this question.

It is thus that in the same phrase an informant could state that to be Quilombola "is to have black skin, like me," and then add "My grandfather wasn't black, he was like me." This paradoxical affirmation recurs in the context of quilombola claims (see also Boyer, 2002: 169).

Through the intervention of the INCRA, the identification and demarcation of the quilombola territory of Cunani was pushed through in 2004, though without passing the step of ratification because the anthropological study was - and still is - missing. The ICMBio (Chico Mendes Institute for Biodiversity, now in charge of National Parks and Protected Areas) also requested a study, not on the real character or the quilombola ascendance, but questioning the 36,000 ha (22,000 of which are in the Park) attributed to this community in decline.

These risks split the movement, some of whom (residing in Calçoene) wanted to invest in tourism by promoting the quilombola identity, while others, more pragmatic, wanted to start a cooperative with the aim of commercializing açaí. Faced with an uncertain future, migration to Calçoene went on, to the point that the school at Cunani went from 12 students in 2007 to only 5 three years later.

\subsection{Abuí, a quilombola community in the Trombetas valley}

During the pre-Columbian period, the valley of the Trombetas river was occupied by various Amerindian groups (Porró, 2008). At the beginning of the 17th century, Europeans occupied the Amazon valley, establishing cacao plantations and cattle ranches in the region of Óbidos, Santarém, and Belém. Following this period, African slaves were imported from the Gulf of Guinea. But the number of slaves escaping rapidly multiplied, and the fugitives organized themselves into communities along the branches of the Amazon. As punitive expeditions increased, the groups of fugitives spread out, going back up the main branch of the Trombetas river, seeking a sure refuge upstream from main rapids where navigation was particularly difficult. 
Increasingly, the interdiction of slave trafficking (1850) and the various laws improving the condition of the slaves, and finally the abolition of slavery (1888), led to the displacement of the fugitive slave communities, which nonetheless traded freely with the towns of the region. The Quilombolas abandoned the territories upstream from the Amerindian populations and increasingly resettled the middle course of the Trombetas (Coudreau, 1900).

The peace between the Quilombolas and Brazilian society did not, however, bring them land security. Starting in 1920, the families of merchants increasingly appropriated the lands along the middle of the Trombetas to control the areas of Brazil nuts trees (Castanhais) and practice cattle ranching on the river banks. The merchants used the widespread system of aviamento, wherein the collectors who gathered Brazil nuts on a merchant's land were obligated to deliver all of their production to him, and to get their provisions from his storehouse (Geffray, 1995). This system of patronage disappeared little by little during the 1960s and 70s, when the trade in Brazil nuts slowed.

The population of Abuí grew from the 1960s on, but settlement continued to be relatively isolated until the 1980s. After this period, the land situation in the Trombetas region was redefined many times. The first changes were linked to the installation in 1976 of a mining complex to extract bauxite from the right bank of the river. Shortly thereafter, as an ecological counterbalance to the mine, the federal government set up two protected areas, in 1979 and 1989, on either side of the river, which led to the expropriation of the land of the local communities. It was the merchants, however, being the official owners of the land, who were compensated, while the numerous inhabitants were evicted, sometimes quite violently (Nasuti, 2005). The inhabitants were thus forced to relocate to other villages in the valley, such as Abuí, which saw a major increase in its population.

The environmental measures of this period were even less in harmony with the presence of local populations (Barretto Filho, 2006), which led to the emergence of social movements fighting for the rights of local populations. Thus, in reaction to the evictions, after 1982 the inhabitants of Abuí were strongly mobilized under the guidance of a priest, Father Patrício, who came with the Rural Workers Union to inform the inhabitants of their rights and incite them to organize as an independent community. Thanks to their participation in the gatherings of the "black roots" (raizes negras), the inhabitants of the Trombetas valley found their identity and created an association in 1989 (Associação das Comunidades Remanescentes de Quilombos do Município de Oriximiná - ARQMO). Their territorial demands were expressed in ever more clear terms at the beginning of the 1990s.

In 1995, the community of Boa Vista, the first in the continuum of black communities in the Trombetas valley, was the first quilombola land to be recognized under this statute in Brazil, opening the way for other communities in the region. Thus, among the interstices of protected areas, Indigenous Lands, and the mining complex, five quilombola territories have since been demarcated, comprising 22 communities over an area of approximately 362,000 ha. It was in this way that the land statute of the Abuí community, and its four neighbours ${ }^{2}$, was stabilized in 2003 , thanks to the granting of a land title for the quilombola territory "Mãe Domingas" (61 211,96 ha).

\section{Globalization and market access: Economic strategies and their impact on forms of development}

Populations that depend on extractive activities adapt continuously to the conditions of the market. They reconfigure themselves very quickly in the face of a changing socio-economic

\footnotetext{
${ }^{2}$ The communities of Paraná do Abuí, Tapagem, Sagrado Coração, and Mãe Cué.
} 
environment. Diversification of revenues is thus vital, when the object of public politics is to support the empowerment of local populations through aid to development. Public authorities, unfortunately, is discontinuous (Greissing et al., 2008), and depends largely on global orientations targeting sometimes environmental conservation, sometimes the fight against poverty. The object of this second section is to describe the relationship between economic choices and forms of development, this relationship having an indirect impact on environmental conservation (Kramer et al., 2009). For access to joint ownership of land does not mean an end to problems of subsistence. Even in extractive reserves, demarcated as a function of economic projects, the inhabitants often have to turn to unforeseen alternatives (as, for instance, cattle in the PAE Chico Mendes - Pantoja et al, 2009). And while the quilombola statute allows people to benefit from certain advantages in terms of cultural funding and access to education, it does not offer, in itself, a means of subsistence, at least for those who live far from tourist itineraries. The Quilombolas thus need to strengthen institutional alliances and commercial partnerships in order to stabilize their access to commodities and services.

\subsection{Açaí, an expanding global market in Cunani}

Among the plant species exploited by the villagers of Cunani, açaí is without doubt that which has gained most in economic value over the last few years. Açaí in effect is the perfect example of a local product that has become the target of a globalized market, avid for new and "ecological" products (Brondizio, 2002, 2008).

Although it has always been the object of local and seasonal consumption, this resource is now exploited for commercial ends by almost all families. Harvesting of açaí takes place from February to May/June. The harvest is often done with the help of brothers and sisters, children or nephews gone to live in Calçoene. The quantity gathered varies greatly according to the family: from 200 to $1500 \mathrm{~kg} /$ day on average according to the workforce, density, and distance to the açaí palms. The revenues tied to açaí corresponds to a large part of their annual household income (this revenue may complement the salaries of teachers, nurse aids, or watchmen, or even retirees and welfare recipients). However, the harvest is very irregular because of the heavy rains that fall during this time of year (the rainy season runs from January to June).

As opposed to other local produce, and in particular to manioc flour whose sale is strictly limited by the high cost of transport to take it to town, the problem of transporting sacks of açaí poses no problem. The buyers, coming from Calçoene or Macapá, go to the entrance of the village to load the produce. This in large part explains the importance of the commercialization of the fruit of this species in relation to other product. The açaí is then resold in Calçoene for up to $3.5 \mathrm{R} \$ / \mathrm{kg}$, and even more in Macapá. Paradoxically, the number of trucks loaded with açaí between February and May make the route impracticable for the rest of the year, contributing to the rise in the cost of transporting people as well as other product.

There is no management, properly speaking, of "wild" açaís, also called "natives": the villagers can use the wild stocks without really appropriating them for themselves, whence the fact that the gathering areas vary yearly ("Não tem açaizal fixo"). They are considered to be open access to all the members of the village, as well as people originally from Cunani living in town. These wild açaís are found in family fields, on the banks of the river, or in the igapós situated in Terra firme forests, without there being any quotas for gathering imposed. On the other hand, the occasional but repeated harvesting of the wild açaís by people outside the community is denounced by the locals. Certain among them know how 
to take advantage of this fad for the "black gold" by renting their açaís or demanding a tax on each $50 \mathrm{~kg}$ sack taken (a practice called matança).

Apart from the "wild" açaís, there are also "cultivated" açaís (according to local terminology): these include açaís not planted but the object of special management (manejado) as well as planted açaís: the palms that are too big or old are cut down to give more space to the productive açaís. But there are also açaís directly planted in swidden fields. This cultural practice aimed at the plantation of açaí on a large scale - more than 5000 açaí trees planted around the vila - is very recent (five years) and its appearance coincides with the strong economic value of this species in the region. In both cases, the açaí plantations are no longer considered to be of open access: the other inhabitants can only gather fruit there on the condition that they are authorized by the owners of the plants.

But the inhabitants who remain in Cunani, held by family loyalty towards their family in Calçoene, cannot pretend to have exclusive rights to the collection of açaí. What is more, the dependence of the inhabitants vis-à-vis the intermediaries and buyers engenders a loss of control over the açaís in the future perimeter of the quilombola territory. These "buyers" purchase the sacks sold by the inhabitants, and profit from illegal exploitation of the palms in the region by importing cheap labor from town. Thus, because of lack of regulation, certain inhabitants of Calçoene with access to means of transport, whether or not they have family ties with the local population, can with little expense obtain a large part of the production.

The practice of one of the principal families of the village, which consists of recruiting outsiders to harvest its açaís, illustrates the difficulty the community is faced with to unify in order to create a cooperative. With no collective organization, the greater value given to a particular hierarchy results in an individual appropriation of resources (the populations of açaís) and a certain concentration of wealth, even without the existence of private property, just as in Abuí with the introduction of cattle ranching. In this case, the recognition of collective quilombola land does not seem to be sufficient to avoid this socio-economic differentiation.

\subsection{Brazil nuts and introduction of cattle ranching in Abuí}

The principal economic activity of Abuí is the collection of Brazil nuts. This is an important activity for not only is it the principal source of income for the community (or at least it was until very recently), but it is also a source of local identity since the Quilombolas of the Trombetas River have been used as the labour source for the collection of Brazil nuts since the end of the 19 th century.

This activity, which requires long stays in the forest, as well as a familiarity with the territory and the forest itself, carries a strong element of identity (the sharing of knowledge, a feeling of belonging). Collection is a seasonal activity, done after the nuts have fallen until all the areas of collection have been exhausted. Commercialization can occur in the field, with itinerant traders criss-crossing the area during the collecting season, or in town. The second solution is more interesting from a financial perspective, but it presupposes the ability to command transport to Oriximiná $(250 \mathrm{~km})$, something not everyone can do. Since 1998, a cooperative begun by the ARQMO has tried to play the role of intermediary by gathering the production of its associates and then transporting the nuts to be sold in town, but its somewhat chaotic management and the ties that continue to unite certain merchants and families of Quilombolas have led to this initiative remaining somewhat marginal. However, the production of the Brazil nuts from Abuí has not yet found its place in 
alternative circuits (fair trade, green, sustainable) because the cooperative has not succeeded in renewing its commercial partners. Thus, the Quilombolas of Trombetas have not found the means to convince their buyers of the value of the ethical/sustainable mode of their collection in order to obtain a higher sales price.

The Brazil nut groves are "communal", which means that there is not a right of preemption of an "owner" over such or such an area. The first comer can thus collect wherever he sees fit. In Amazonia, such a system is less frequent than the system of colocação, which holds for the collection of latex from rubber trees (Hevea brasiliensis), and in which a family is entitled to the collection of a demarcated area. But this system is not as open as it appears since there are secret collection zones known to a single family that one avoids showing to others.

A better organization of production, or the possibility of adding to the value by an initial processing in the field, would probably be an important factor to intensify exploitation, which is currently in decline. Cattle ranching is now the fastest growing alternative. Even there are not more than 100 head of cattle in Abui, the phenomenon is particularly recent and rapid, the village having passed from one to thirteen ranchers since 1995 . The introduction of monetary revenue, tied to the rise in salaried functions (teachers, health agents, school boat drivers, etc.) with external economic activities (salaried work around the Trombetas mine) or with social benefits (rural retirees, etc.), gives to some the possibility of investing small amounts of capital. Instead of risking it in Brazil nuts, a seasonal activity of uncertain return because of the oscillations in price, families prefer to invest in raising animals, where the return is guaranteed and which allows for savings until they have enough head of cattle to finance a large purchase (boat, motor, etc.). In addition, the practice of share breeding 3 by the two principal ranchers of Abui shows that the chain of production is controlled by the political and commercial elite located in Oriximiná. The outlets for ranching are thus guaranteed through these political connections, which grant access to the municipal slaughterhouse.

But another phenomenon should be underscored here. The recognition of the quilombola territory Mãe Domingas was made in the context of an alliance between the people of the forest and the environmental movements. In this context, collection activities such as that of Brazil nuts were favoured, and ranching, which is considered as a vector of deforestation, was very marginal and little practiced. Once their territory was recognized, the Quilombolas of Abuí found themselves in a situation of land security, and it is possible that this new context favoured the increase in ranching. In effect, the alliance with the environmental movements became less indispensable to them, since the territory was now guaranteed, which may have led them to give in to a certain economic realism, encouraging a more profitable activity to the detriment of that which offered less financial security. One might thus put in parallel the marked weakening of the cooperative of the ARQMO, which barely functions, and the increase in the number of ranchers.

\section{Migration routes and urbanization}

The profound integration of the urban and rural worlds in Amazonia, which leads one to talk of "rural cities and urban forests" (Padoch et al, 2008), corresponds to a very old tradition

\footnotetext{
${ }^{3}$ Arrangement in which a big rancher, having productive capital and generally living in town, places his cattle in several small ranchers' fields, who, in exchange for half of the production, plant and maintain the pasture (Cochet et al., 2010).
} 
of multi-sited households. Previously arising from socialization needs (feasts of the saints) and the commercialization of extractive and agricultural products, these multiple residences today are motivated, among other things, by access to care, education for children, and paid employment.

Thus, with globalization, the traditional populations of Amazonia make up increasingly diverse and extended socio-spatial networks (Granchamp, 2001; Padoch et al., 2008). This mobility is accompanied by the transformation in types of residency, the dispersion and fragmentation of social groups, and the hybridization of knowledge and identity, but also the reconfiguration of use and rights to resources (Alexiades, 2009; McSweeney and Jokisch, 2007; Eloy and Le Tourneau, 2009). The impact of this rural-urban mobility on resource management and the socio-demographic behaviour of the Quilombolas depends on land tenure issues but also on the nature of social and commercial networks established with the town, which are nested in a particular economic and political context. In addition, means of transport play a key role in these recompositions, the high cost of which can only be deemed worthwhile if individuals maintain strong ties with the community from whence they come. In this light, the two villages studied present strongly contrasting profiles.

\subsection{The decline of Cunani, an irreversible phenomenon?}

In the 1930s, a large landowner from Belém brought employees from Marajó and Vigia to work in his agricultural lands located at the mouth of the Cunani River. The population naturally increased, with a mixture of inhabitants from upstream and downstream, until it reached approximately 300 people. At that time, the settlement pattern was dispersed (retiros), with main houses located near swidden fields.

The construction of a public school led to families relocating to Vila Cunani around 1940/45. The village began to become more lively, notably during the religious festivals of Santa Maria in August, and São Benedito in December. However, the school stopped at the primary level, and the children could not pursue their education past the fourth year. Some of them were taken in by a godfather or godmother (compadre or comadre) in the main towns of the State of Pará (Belém, Vigia). A first generation of migrants was thus formed outside of Cunani but came back to marry, set up house, and raised on average eight children. These movements were periodic - most often for several months - and were organized around economic opportunities: an initial migrant calling others to the towns of Calçoene, Macapa, Belém, Oiapoque, and Cayenne, in order to work there in carpentry, gold mining, agriculture, and warehouse work. Then, during the 1980s, in order to be able to educate their children, the families moved definitively to Calçoene, which had become a regional economic centre since the opening of BR156.

As a consequence, families started to sell their "retiros" to buy land and have a house built in Calçoene, while keeping a house in Vila Cunani in case of an eventual return. Cunani has seen its population fall, going from 250 in 1970 to 26 in 2010, 16 of whom are more than 40 years old. The majority of children are raised in Calçoene (nearly 9000 inhabitants), then in Macapa and/or Belém for now, as they say, "Cunani is outdated". Except for the period of gathering açaí, when the inhabitants of Calçoene come to help their families, and fishing or hunting during the vacations, the younger generations (15 - 25 years old) refuse to stay in this town in decline, with neither running water, electricity, or internet access. 
According to our interviews, four inhabitants of Cunani also frequent two other villages, Lourenço and Vila União. These are not quilombola communities, but rather places of leisure and religious festivals. But most displacements focus on Calçoene, followed by Macapa and then Oiapoque.

Calçoene fulfills a number of possible functions (economic, social, services) and brings together visits of relatives (the equivalent of Oriximiná for Abuí). Macapá (the capital of Amapá) is essentially visited for family and not for economic reasons, similar to how Manaus is visited by people from Abuí (see below). Trips to Oiapoque, exclusively tied to IBAMA/ICMBIO, are made by men and concern community interests.

Figure 2 shows the dispersion of the kinship network of people from Cunani, living in Cunani, or having migrated to Calçoene fewer than 30 years ago. It shows that the families are dispersed exclusively among the towns, since no village appears in the network, which confirms the process of a rural exodus on a regional scale. The network confirms the preponderance of Calçoene in the social organization of Cunani. The residents of Cunani have most of their relatives in this town and in Macapa. Individuals having their families the most dispersed (3A, 5A, and 8C, at the centre of the network) are inhabitants of Cunani. These are among the oldest families of Cunani, who are looking to diversify their activities (trainings at IBAMA, plantations of açaí), which explains their dispersion. On the other hand, it seems that the inhabitants of Calçoene, living on commerce, social benefits, and agriculture, have no need to disperse in this way to develop their activities. The area of dispersion for women is smaller than that for men, though more qualitative, both as to length and frequency.

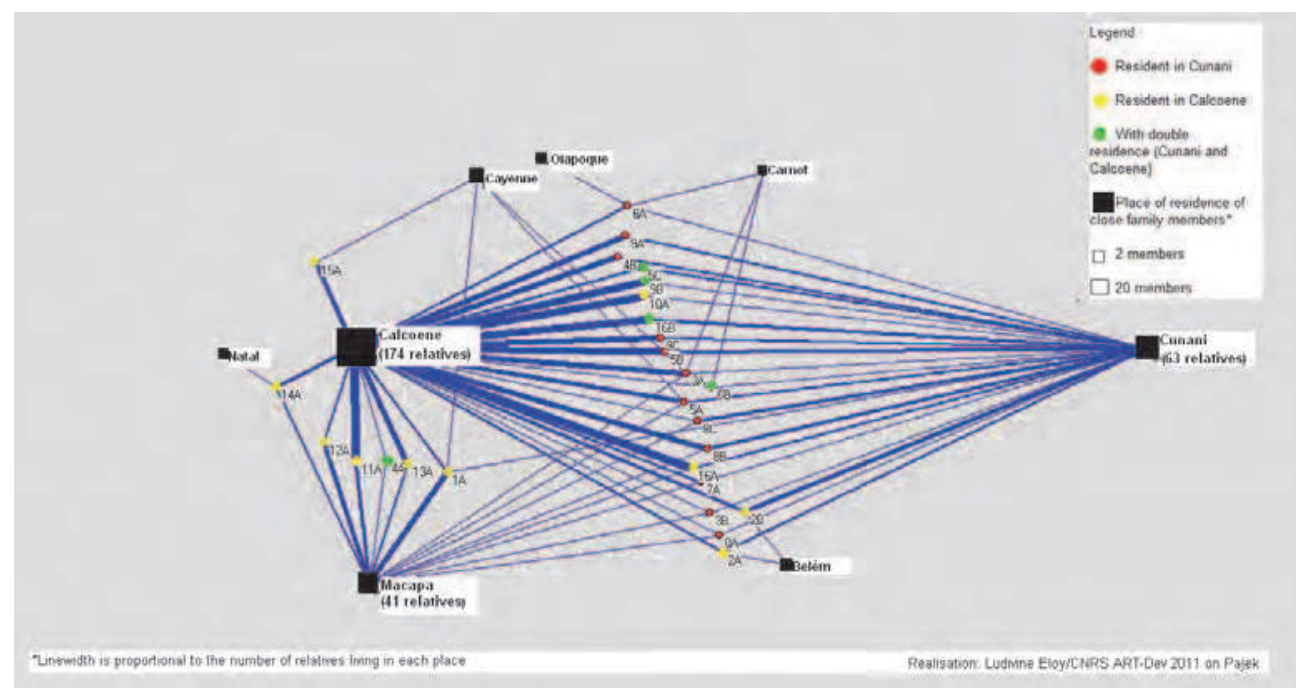

Fig. 2. Spatial dispersion of the kinship network of the inhabitants of Cunani and migrants from Cunani recently moved to Calçoene (29 surveys) ${ }^{4}$

\footnotetext{
${ }^{4}$ Considered as relatives in this graphic: father, mother, brothers and sisters, children, step-brothers and adopted children included, as well as current spouses.
} 
Thus, following the analysis of Domenach and Picouet (1987), thinking about the reversibility of migrations - and its corollary, irreversibility - allows us to highlight the importance of networks. The myth of return remains present in many discourses, as much for the affective ties as for the quality of life in the village. Once they have left, however, no family has returned to Cunani - with the exception of one person who had a serious accident - and the pensions of the retirees does not allow the migrants as frequent return visits as they might wish for. The oldest inhabitants would rather finish their days close to their children, in the hospital at Calçoene. Such a choice shows the increasing rootedness of the inhabitants of Cunani in the neighboring town of Calçoene. The analysis by network shows that the geographic mobility towards Calçoene may also constitute a step before that towards Macapa, where the university is a strategic asset for the younger generations.

Is the quilombola statute, on its way to recognition, a possible means of reversing this tendency? The funds released by the Secretary for Minorities, and given to the Quilombolas in the State of Amapá, can no longer be invested in local education, due to the lack of students. The teacher, who is also the president of the village association, has therefore proposed the building of a new community center, in the shape of an indigenous long house, or Maloca, thus hoping to give some prestige to the village; such an option, which shows the difficulty of characterizing culturally the Quilombolas of Brazil, would without doubt be the last major investment for the community.

\subsection{Abuí: A successful integration within global dynamics?}

Faced with the devaluing of extractive products and the rise in monetary needs, the Quilombolas of Abuí need to find new activities. A modification of the spaces frequented by members of the community can thus also be seen, tied to new social functions.

The study of the frequency and reasons for mobility reveal two principal modes of circulation outside the village. The short distance visits to the surrounding villages arise from "tradition" motivated by religious festivals, sporting events, and occasional visits to relatives. Displacement towards the towns deal above all with economic activities. These essentially concern Oriximiná: throughout the history of extractive activities in the region, the town has been a place of exchange and sale of extractive products for manufactured ones. But the frequency of displacements to Oriximina seems to have increased these past few years, as the acquisition of a community boat as well as individual motorboats allow people to travel the $250 \mathrm{~km}$ of river in a single day, in contrast to many days in a pirogue. In $71 \%$ of the cases, people from Abuí say they go there at least once a month. This increase in the frequency of travelling to town is motivated by the growth of social benefits (accessible in town) since the Lula government (2003) as well as opportunities for salaried work. These are essentially jobs for women: the majority of young women from Abuí take their chances as house workers while pursuing their studies in Oriximiná, whereas the young children stay with their grandparents in Abuí. This growing interaction with Oriximiná is thus expressed in the construction of multi-sited residential systems (or multi-sited households) between town and forest ${ }^{5}$.

\footnotetext{
${ }^{5}$ The residential system is an articulated group of places of residence for the members of an extended family (Le Bris, 1986\}.
} 
On the other hand, Porto Trombetas, located halfway between Abuí and Oriximiná, is much less frequented: most visits occur fewer than four times a year. Porto Trombetas essentially fulfils a function of access to health services. It is in effect a town built in the 1970s for skilled workers from the mining industry, and which had no role in the extractive economy. Visiting Porto Trombetas and the settling of families in nearby quilombola villages (such as Boa Vista) are strictly regulated and limited to avoid urbanization along the river in proximity to the mines (Nasuti, 2005). Faced with protests from the quilombola communities, the mining industry made the hospital at Porto Trombetas accessible in case of emergency, which explains such unusual displacements to this town. Porto Trombetas is also a destination for temporary work, but as opposed to Oriximiná, it is essentially work for men, tied to the mines. The regional towns, further away, such as Óbidos, Santarém, and Manaus, are less often cited, since they are visited only occasionally. Manaus is cited only as a place to visit relatives, who have left Abuí for good to work there.

Thus, the effects of recent urbanization in Abuí reflect in the extension of kinship networks in regional towns. Figure 3 shows that Abuí is where the majority of relatives reunite. The family network also links Abuí to other quilombola villages in the region (Tapagem, Sagrado Coração, Boa Vista, Erepecu), which reveals, as opposed to Cunani, the anchoring of this social structure in the rural setting. However, most of the people surveyed are situated between these three poles (Abuí, Oriximiná, and Manaus), which means they have close relatives in the two towns, notably Oriximiná, where they have older relatives as well as some younger ones (secondary school students, house workers). It can thus be said that most of the inhabitants of Abuí belong to multi-sited residential systems that link

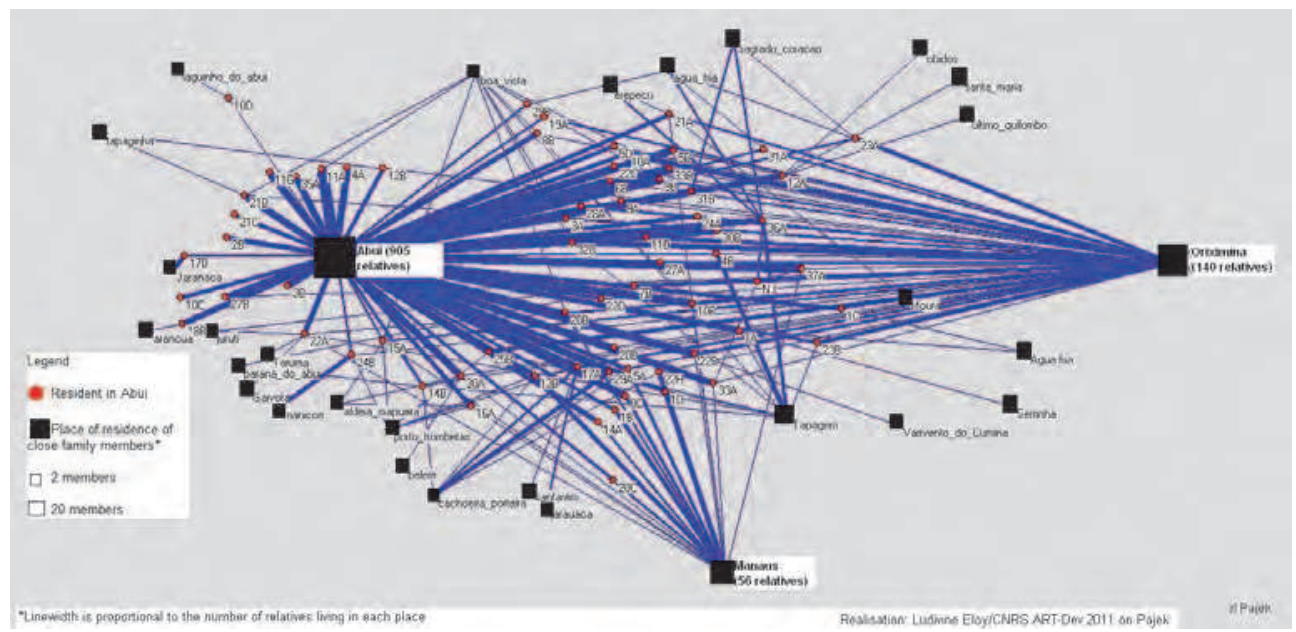

Fig. 3. Spatial dispersion of the kinship network for the inhabitants of Abuí (76 surveys)

the legalized quilombola territory with regional towns offering economic alternatives to the crisis of extractivism. Instead of engaging in a process of rural exodus, the people of Abuí seek out available resources in different spaces by intensifying their movements into the towns. The polarized movements to towns are thus superimposed on the "traditional" movements between the other quilombola villages without replacing them. 


\section{Conclusion}

The two quilombola communities studied are confronted with the contradictory effects of globalization: while they are subject to increasing environmental restrictions because of the proximity to and juxtaposition with conservation areas, they are increasingly integrated within a globalized market and a formal education system. In this way, our research brings into evidence the increasing disjunction between territory and identity produced by globalization (Appadurai, 1995). In effect, as with other traditional populations in Amazonia (Eloy and Lasmar, in press; Moreira, 2003 ; Padoch et al., 2008), there is a growing gap between, on the one hand, a demarcated territory, associated with a specific identity, and on the other, the socio-economic reality anchored in towns and articulated around individual strategies. These manifestations of globalization are expressed in a change in the use of resources but also in the extension of family networks in the regional towns. However, the function and form of these networks differ between the two communities.

In Cunani, after the construction of the BR and the creation of the National Park, the decade from 1980 - 90 was marked by migratory circulation and dual residency between Cunani and Calçoene. With the restrictions imposed by the IBAMA on river transport, most of the inhabitants opted for a definitive migration to Calçoene, as individual transport by road became too onerous. The perspective of the creation of a quilombola community at Cunani was not enough to halt the rural exodus. In addition, the local production of açaí, being seasonal, was not enough to keep the new generations in place. In this context, swidden cultivation is increasingly replaced by plantations of açaí requiring less labour, confirming a process of deagrarisation already observed in other communities in Amapá (PinedoVasquez and Padoch, 2009). At present, the periodic and seasonal movements that link Cunani to Calçoene are motivated essentially by festive events and the production/commercialization of açaí. The social and commercial network of Cunani is thus centred around Calçoene and other regional towns.

In contrast, in Abuí, because of the devaluing of extractive products, land tenure security functions as a resource to free up new revenues that are complementary to or even dependent on urban resources (e.g. share breeding, social benefits, and paid employment). Despite the distance that separates Abui from Oriximiná $(250 \mathrm{~km})$, the inhabitants have constructed multi-sited households between town and forest that rely on intensive river transport. The improvement in the level of livelihoods and the collective organization of river transport has been an essential factor in these socio-demographic adaptations. The mobility thus constitutes a "circulatory resource" (Cortes, pers. comm.) for the rural populations of Amazonia.

In both cases, the emergence of productive values brings with it the individual appropriation of resources (açaí plantations and pasture lands) and a certain concentration of wealth in the hands of a few families, and this even without private property. Thus, the recognition of collective quilombola lands would not be enough to halt the tendency towards socio-economic differentiation. The introduction of ranching in the quilombola villages of Trombetas, driven by the urban political elite through share breeding, indicates that land is not a privileged factor in the concentration of capital (Cochet et al., 2010).

Nevertheless, we cannot affirm that the land tenure security accorded to the Quilombolas of Trombetas explains and justifies in itself the introduction of cattle ranching. The fact that 
the quilombola lands are not under conservation restrictions leaves the owners free to exploit the resources as they see fit. And yet the introduction of ranching is also explained by the privileged relation that two families from Abuí have with a rancher from Oriximiná, which has allowed them to bring the initial productive capital (cattle). It is this type of network that the other community studied, Cunani, was not able to consolidate.

Thus, while the proximity to roads is known to be the principal factor determining the expansion of cattle ranching (Chomitz et al., 2007; Scouvart and Lambin, 2006), in this case the community that began this activity is precisely the one which is not connected to the road network and is furthest away from town. It seems therefore that the impact of globalization on land use of traditional populations is not uniquely determined by geographic factors (remoteness, land rights), but also depends on the access to mobility and the socio-cultural networks that these populations construct with different agents of development in Amazonia (urban political elites, businesses, NGOs).

\section{Acknowledgements}

Our study, financed by the French Agence Nationale de la Recherche, is part of USART program (Uses and transmission of territorial knowledge in traditional Amazonian context). Our fieldwork period was July and August 2010. We are grateful to all the farmers from Cunani and Abuí for their patience and kindness. Thanks to Kevin Frey for his accurate and rapid translation of this text.

\section{References}

Alexiades M. N., 2009, Mobility and migration in indigenous Amazonia: contemporary ethnoecological perspectives, New York, Oxford,Berghahn.

Appadurai A., 1995, «The Production of Locality », in FARDON Richard, Counterworks Managing the Diversity of knowledge, New York, Routledge : 204-225.

Appadurai A., 1996, Modernity at Large: Cultural Dimensions of Globalization, Chicago, University of Minnesota Press.

Barretto filho H. T., 2006, “Populações tradicionais: introdução à crítica da ecologia política de uma noção", In: Sociedades Caboclas Amazônicas: Modernidade e Invisibilidade. C. Adams, R.S.S. Murrieta, and W.A. Neves (eds.). São Paulo, Ana Blume : 109-144.

Boyer V., 2002, «Quilombolas et évangélistes: une incompatibilité identitaire ? Réflexions à partir d'une étude de cas en Amazonie brésilienne », Journal de la Société des Américanistes, 88 : 159-178.

Brondizio, E.S., et al., 2002, The urban market of Açaí fruit (Euterpeoleracea Mart.) and rural land use change: Ethnographic insights into the role of price and land tenure constraining agricultural choices in the Amazon estuary. Urban ecosystems 6 (1/2): 67-98.

Brondizio, E. S. 2006. Landscapes of the past, footprints of the future: historical ecology and the analysis of land use change in the Amazon. In W. Balée and C. Erikson (eds.) Time and Complexity in Historical Ecology: Studies in the Neotropical Lowlands. New York, Columbia University Press: 365-405.

Brondizio, E. S. 2008.The Amazonian Caboclo and the Açaí palm: forest farmers in the global market. New York Botanical Garden Press, New York, New York, USA. 
Bunker, S., 1985, Underdeveloping the Amazon. Extraction, unequal exchange, and the failure of the modern state, Chicago, University Of Chicago Press.

Chomitz K. M., Buys P., De Luca G., Thomas T. S., Wertz-Kanounnikoff S., 2007, At Loggerheads?Agricultural Expansion, Poverty Reduction, and Environment in the Tropical Forests.Washington: The World Bank.

Cochet, H., Leonard, E., Tallet, B., 2010, «Le métayage d'élevage au Mexique. Colonisations foncières et dynamiques d'une institution agraire dans l'histoire contemporaine ", Annales de géographie 6 (676) : 617-638.

Coudreau, H.,1900,Voyage au Trombetas. 7 août 1899-25 novembre 1899, Paris, A. Lahure.

Diegues, A. C., 1996, O Mito moderno da Natureza intocada, São Paulo, Editora Hucitec NUPAUB/USP.

Domenach, H., Picouet, M. 1987. «Le caractère de réversibilité dans l'étude de la migration », Population, 3: 469-484.

Eloy L., 2008, «Diversité alimentaire et urbanisation. Le rôle des mobilités circulaires des Amérindiens dans le Nord-Ouest Amazonien». Anthropology of food,vol. S4, p. http://aof.revues.org/document2882.html

Eloy L.,Le tourneau F. M., 2009, «L'urbanisation provoque-t-elle la déforestation en Amazonie ? Innovations territoriales et agricoles dans le nord-ouest Amazonien (Brésil)». Annales de géographie (Paris), vol. 118, $\mathrm{n}^{\circ} 667$ : 204-227. search.ebscohost.com/login.aspx?direct $=$ true \&db=fcs\&AN=21936449\&amp;lang $=\mathrm{f}$ r\&site $=$ ehost-live

Geffray, C., 1995,Chroniques de la servitude en Amazonie brésilienne. Essai sur l'exploitation paternaliste. Paris, Editions Karthala.

Granchamp F. L., 2001,Urbanisation, stratégies familiales et multipolarité rurale-urbaine: la transamazonienne à l'ouest d'Altamira (Pará, Brésil). Thèse de doctorat. Paris: EHESS, Centre de Recherche sur le Brésil Contemporain, 386 p.

Greissing A., Kohler F., Le Tourneau F.M., Picanço J.R.A, 2008, «Iratapuru et la noix du Brésil: une expérience de durabilité en Amazonie brésilienne ", Cybergeo, Environment, Nature, Landscape, Article 432, http:/ / cybergeo.revues.org/20763

Harris M., 2006, "Presente ambivalente: uma maneira amazônica de estar no tempo", in: Sociedades Caboclas Amazônicas: Modernidade e Invisibilidade. C. Adams, R.S.S. Murrieta, and W.A. Neves (eds.). São Paulo, Ana Blume: 81-108.

Kramer D. B., G. Urquhart, K. Schmitt, 2009, Globalization and the connection of remote communities: A review of household effects and their biodiversity implications, Ecological Economics 68 (2009) 2897-2909.

Lebris E., 1986, «Synthèse des travaux sur la mobilité interne et externe dans le Sud-Est Togo».In E. Le Bris, G. Pontié, A. Quesnel, J. Gregory, M. T.Duquette-Ahado and K. Vignikin (eds.), Migrations togolaises: bilan et perspectives. Lomé: Université du Bénin. Unité de Recherche Démographique (TGO) : 255-282.

Mcsweeney K., Jokisch B., 2007, «Beyond Rainforests: Urbanisation and Emigration among Lowland Indigenous Societies in Latin America ». Bulletin of Latin American Research, vol. 26, $\mathrm{n}^{\circ} 2: 159-180$.

Moreira E. L. (2003). «Amazônia em movimento: Redes e Percursos de Desenvolvimento dos Índios Ye'kuana, Roraima». Cadernos de Campo (USP),vol. 11. 
Nasuti S. (2005). Infrastructures industrielles et communautés: stratégies territoriales. Vallée de Trombetas, Etat du Pará - Brésil, Master. Paris: Université Sorbonne NouvelleParis III, IHEAL.

Padoch, C., E. Brondizio, S. Costa, M. Pinedo-vasquez, R. R. Sears, and A. Siqueira, 2008, Urban forest and rural cities: multi-sited households, consumption patterns, and forest resources in Amazonia. Ecology and Society 13(2): 2. [online] URL: http://www.ecologyandsociety.org/vol13/iss2/art2/)

Pantoja, M. C; Costa, E.; Postigo, A., 2009, “A presença do gado em Reservas Extrativistas: algumas reflexões". Caderno Pós Ciências Sociais. v.6 n.12 jul/dez, São Luis/MA: UFMA.

Pinedo-Vasquez M., Padoch C., 2009, «Urban and rural and in-between: Multi-sited households, mobility and resource management in the Amazon floodplain», In M. ALEXIADES (ed.), Mobility and migration in indigenous Amazonia. Oxford, Berghahn books : 86-96.

Porró, A., 2008,"Notas sobre o antigo povomaento indígena do Alto Trombetas e Mapuera",Boletim do Museo Paraense Emílio Goeldi, vol.3 n³, p.387-397.

Ricardo, F., rolla, A. 2009. Amazonia brasileira. Sao Paulo: InsitutoSocioambiental.

Scouvart M., Lambin E. F., 2006, «Approche systémique des causes de la déforestation en Amazonie brésilienne. Syndromes, synergies et rétroaction», Espace Géographique, vol. $35, \mathrm{n}^{\circ} 3: 241-254$.

UNESCO, 2003, Cultural Diversity and Biodiversity for Sustainable Development: a jointly convened UNESCO and UNEP high-level Roundtable held on 3 September 2002 in Johannesburg, South Africa during the World Summit on Sustainable Development: http://unesdoc.unesco.org/images/0013/001322/132262e.pdf

Veran J.-F., 2002, «Quilombos: des 'lieux de mémoire' bien vivants », Cahiers du Brésil Contemporain $n^{\circ} 49-50$ : 87-96. 


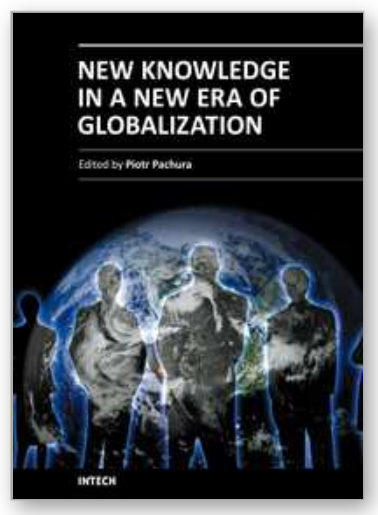

\author{
New Knowledge in a New Era of Globalization \\ Edited by Prof. Piotr Pachura
}

ISBN 978-953-307-501-3

Hard cover, 354 pages

Publisher InTech

Published online 01, August, 2011

Published in print edition August, 2011

To better understand the contemporary world, the world of innovation and technology, science should try to synthesize and assimilate social science in the development of our civilization. Does the new era require new knowledge? Does the age of globalization demand new education, new human attitudes? This books tries to clarify these questions. The book New Knowledge in a New Era of Globalization consists of 16 chapters divided into three sections: Globalization and Education; Globalization and Human Being; Globalization and Space. The Authors of respective chapters represent a great diversity of disciplines and methodological approaches as well as a variety of academic culture. This book is a valuable contribution and it will certainly be appreciated by a global community of scholars.

\title{
How to reference
}

In order to correctly reference this scholarly work, feel free to copy and paste the following:

Florent Kohler, Ludivine Eloy, François-Michel Le Tourneau, Claire Couly, Stéphanie Nasuti, Dorothée Serges, Sophie Caillon, Guillaume Marchand and Anna Greissing (2011). Globalization in the Brazilian Amazon Region: Conflicting Answers from "Quilombo" Communities, New Knowledge in a New Era of Globalization, Prof. Piotr Pachura (Ed.), ISBN: 978-953-307-501-3, InTech, Available from:

http://www.intechopen.com/books/new-knowledge-in-a-new-era-of-globalization/globalization-in-the-brazilianamazon-region-conflicting-answers-from-quilombo-communities

\section{INTECH}

open science | open minds

\author{
InTech Europe \\ University Campus STeP Ri \\ Slavka Krautzeka 83/A \\ 51000 Rijeka, Croatia \\ Phone: +385 (51) 770447 \\ Fax: +385 (51) 686166 \\ www.intechopen.com
}

\author{
InTech China \\ Unit 405, Office Block, Hotel Equatorial Shanghai \\ No.65, Yan An Road (West), Shanghai, 200040, China \\ 中国上海市延安西路65号上海国际贵都大饭店办公楼405单元 \\ Phone: +86-21-62489820 \\ Fax: +86-21-62489821
}


(C) 2011 The Author(s). Licensee IntechOpen. This chapter is distributed under the terms of the Creative Commons Attribution-NonCommercialShareAlike-3.0 License, which permits use, distribution and reproduction for non-commercial purposes, provided the original is properly cited and derivative works building on this content are distributed under the same license. 